\title{
Family Names and the Cataloger
}

\section{By Laurence S. Creider}

Laurence Creider (Icreider@lib.nmsu. edu) is Head of the General Cataloging Unit in the University Library of New Mexico State University, Las Cruces.

I wish to thank Robert Maxwell of Brigham Young University for comments and suggestions on an earlier draft. That earlier draft was completed before the Library of Congress issued its proposal for treating family names, and some of examples used in that draft appeared in the Committee on Cataloging: Description and Access response to the LC proposal. This paper mentions the Library of Congress proposal in passing but was submitted prior to the consideration of family names by the Joint Steering Committee for Revision of Anglo-American Cataloguing Rules scheduled for March 2007.

Submitted August 3, 2006; tentatively accepted pending revision October 11, 2006; revised and resubmitted December 28, 2006; accepted for publication January 3, 2007.
The Joint Steering Committee for the Revision of the Anglo-American Cataloguing Rules has indicated that the replacement for the Anglo-American Cataloguing Rules, 2nd ed., to be known as Resource Description and Access, will allow the use of family names as authors and will provide rules for their formation. This paper discusses what a family name describes; examines how information seekers look for family names and what they expect to find; describes the ways in which family names have been established in Anglo-American cataloging and archival traditions; asks how adequately the headings established under these rules help users find such information; and suggests how revised cataloging rules might better enable users to identify resources that meet their needs.

$\mathrm{D}$ escriptive catalogers have devoted a great deal of time over the last century to deciding how to establish personal names and corporate names, but they have largely ignored family names. Anglo-American cataloging codes have been based on the notion that authorship is the best basis for organizing access to works, and many library catalogers have not considered the possibility that families can be capable of authorship. One looks in vain for a discussion of families as points of entry or as headings in the comparative studies of cataloging codes written by Pettee, Hanson, or Ranganathan. ${ }^{1}$ The Paris Principles adopted in 1961 do not even mention the word family. ${ }^{2}$ This state of affairs has persisted from the days of Cutter through the various Anglo-American cataloging codes, as a glance at the indices and tables of contents of such works reveals. ${ }^{3}$ For example, the index of the second edition of the Anglo-American Cataloging Rules (AACR2), refers the user from "Family names" to "Surnames," which are used only for individual persons in chapter $24 .{ }^{4}$ The closest such codes come to considering family names is identifying surnames for individual persons and indicating that firms bearing the name of a person need to be entered under surname. ${ }^{5}$

Nonetheless, catalogers currently use family names when cataloging books about families, and archivists have a tradition of entering family papers under the name of the family responsible for the collection. ${ }^{6}$ This paper will discuss how families act as agents and create collections of papers, including objects, letters, records of real estate transaction, or photographs. Traditional cataloging rules are unable to deal with materials such as these except through makeshift means, such as title main entry with an added subject entry for the family involved. Such means result in the inability of catalogers to describe such materials properly, and users encounter difficulties in accessing those materials. The neglect of this area by descriptive catalogers appears likely to change with the revision of AACR2, as the rules devised for part three of the intended replacement, Resource Description and Access (RDA) are supposed to contain rules for establishing names of families. ${ }^{7}$

This plan is in accordance with the draft Statement of International Cataloguing Principles issued by the International Federation of Library 
Associations and Organizations (IFLA) Meeting of Experts on an International Cataloguing Codes that "If a person, family, or a corporate body uses variant names or variant forms of names, one name or one form of name should be chosen as the authorized heading for each distinct persona." Unfortunately, the few statements in the International Cataloging Principles that concern the formation of family names (5.1.2.1.1.1-2) and the choice of entry elements (5.3) are much too vague to provide aid to the cataloger. The Library of Congress has proposed rule revisions to AACR2 for the formulation of family names. ${ }^{9}$ A fresh look at the problem is necessary.

Such an examination involves several steps. The first is to determine what a family name describes. This is not quite the same as the question of what constitutes a family, but both questions involve some of the same elements. The next step involves asking how information seekers look for family names and what they expect to find. The third step is an investigation of how family names have been regarded and established in the Anglo-American cataloging and archival traditions. The fourth step asks the question how adequately the headings established in accord with these traditions help users find information via family names. The last step is to suggest how $R D A$ might formulate rules that better enable users to identify resources that might fulfill their needs.

\section{What Is a Family Name?}

The first question is best answered by examining what the semantic area covered by a family name is; that is, what does the name name? Without getting into the current political quagmire of what constitutes a family, the cataloger needs to understand what constitutes a family in the work(s) being cataloged, whether or not a family is capable of action, and how family names are formed. Loosely defined, a family is a group of individuals related by ties of kinship and or affiliation, generally living in a household. Relevant portions of the definition for "Family" in the Merriam-Webster Online Dictionary are:

1 : a group of individuals living under one roof and usually under one head : HOUSEHOLD 2 a : a group of persons of common ancestry : CLAN b : a people or group of peoples regarded as deriving from a common stock : RACE $3 \mathrm{a}$ : a group of people united by certain convictions or a common affiliation : FELLOWSHIP $b$ : the staff of a high official (as the President) . . . 5 a : the basic unit in society traditionally consisting of two parents rearing their children; also : any of various social units differing from but regarded as equivalent to the traditional family <a single-parent family $>$ $\mathrm{b}$ : spouse and children <want to spend more time with my family $>{ }^{10}$

In western societies, the most common notion is that such ties are biological, but they may be ties of affiliation, such as marriage. Familial ties also may be formed by a story of common descent, whether or not genetic relations are involved, by formal or informal adoption, by formal or informal association, or by spiritual kinship. As an example of association, a woman might raise the stepchild of her sister's son. While no biological or formal relationship is involved, the parties may consider themselves a family. As for spiritual kinship, during much of the middle ages baptism was held to create kinship ties that meant a godparent could not marry the surviving birth parent if one of the birth parents died. ${ }^{11}$ In many societies, children may not marry their stepparents; that is, they already constitute a family.

Next is the question of extent. How big is a family, and how far does it extend in kinship, space, or time? Because answers to this question have varied, a description of the parameters answers might take would be more useful. A family group may be bounded by period, place, descent, or some combination thereof. Sometimes families self-identify as the descendants of a particular individual; this may or may not include descent through female lines. Klapisch-Zuber, for example, describes how medieval Tuscan families traced their lineage and family names from a common ancestor who might not have been the most distant ancestor who could be traced, and omitted lines that left no issue. ${ }^{12}$

Family may be nuclear or extended; it may consist of one generation or many generations. In what ways does a family differ from a clan, and a clan from a tribe? This last problem is not limited to non-western peoples; it arises also in relation to the Roman gens. The size of the group that the word indicates can range from nuclear family to clan to nations. ${ }^{13}$ Many of the Germanic-speaking and other barbarian groups entering the Roman Empire during the fourth through sixth centuries regarded their members, or their elites, as sharing a common ancestor. The literature concerning ethnic identity in the wake of the Roman Empire has become immense, but archaeologists and historians have come to recognize that these were probably groups formed by individuals adhering to the group and adopting common social identifiers. ${ }^{14}$

Native American kin groups consist of tribes with moieties and clans, and sometimes the boundary between these and what are called families is unclear. The matter becomes particularly complex when the patterns of indigenous peoples are overlaid with the patterns required by a modern nation state. ${ }^{15}$ Under what conditions do families become tribes or ethnic groups? For the cataloger, a family name might refer to groups in any of these categories. Is a family "co-extensive" with its name? This seems unlikely. To take an obvious 
example, a family may have changed its name when individuals changed country, language, or religion. Sometimes name changes have been dictated or encouraged by states. ${ }^{16}$

While many of these groups have names in the sense of a common name element, be it a surname or the gens of classical Rome, others do not. Sometimes a family is known from the location of its major place of residence (Babenburg), sometimes it is deemed a dynasty taking its name from a founder (Capetians of France), and sometimes the family name refers to the holders of a title, even though descent may not be direct at all (Dukes of Devonshire). Surnames taken from the place of residence are not limited to noble families. Rural Finnish households took a surname from the place in which they lived; if they moved, they took the name of the new residence. ${ }^{17}$

Many families have never had names in any formal sense, particularly in pre-modern Europe and portions of Asia and Africa. ${ }^{18}$ When such groups need to be described, they are given some sort of name or denomination, usually put in the terms of the individuals (judges, journalists, historians, anthropologists) who assign the names. The cataloger will be safest to consider a family name as a denomination, describing a group of individuals sharing bonds that the members feel make them a family. The larger society may or may not agree with that assessment.

\section{What Do Users Want to Know about Families and How Do They Look?}

A literature search in several databases uncovered few studies concerning the types of information users of family information are seeking and how they look for it. The studies that were found discussed variant forms of names and the difficulties they pose to researchers. ${ }^{19}$ Therefore, answers to this question can be little more than suggestions drawn from examples of research involving family names. Many users of library and archival information can be said to seek information about a family to better understand their own identity. The specific purpose may be genealogical or historical, or both. A researcher might ask, "Who was my great-grandfather and what did he do? Where did my name come from? Who are the other members of my family and where might I find them?" Such questions may have political, social, legal, financial, and other ramifications, ranging from the opportunity to throw dirt on a political candidate by means of controversial family members, to wanting to join a society such as the Daughters of the American Revolution, to finding the holders of a copyright or a mining claim.

Historians may investigate the history of one or more families as a way of studying historical processes on a more detailed scale. Biographers may be interested in the context provided by an individual's family, or they may be interested in the lives of several members of a family, such as the Roosevelts. Users may be interested in contemporary people who share a family name, or those of a period past. The sources users want access to include the traditional books, journals, or newspaper articles; records such as correspondence, census schedules, marriage licenses, real estate, legal files, and medieval charters; and family papers. These sources can be collected or authored by a family or its members, or might even be government documents. The materials can be in manuscript, online, visual (still and in motion), audio, or other format.

Users may try to find material about or by a family group. They can be very specific in their needs, such as wanting to learn about the descendants of Jacob Hostetter (1791-1859) of Lancaster County, Pennsylvania, as opposed to the descendants of any of several other Jacob Hostetters. ${ }^{20}$ Sometimes the need is very broad, as when an individual wants to find information about all the Millers of Ohio. Other users may want to find information about the individual members of the group, about the family as a totality, or both, as one finds in histories of great mercantile firms such as the Rothschilds or the Morgans. Some researchers may be interested in studying the different families of a particular place in a particular period, such as Renaissance Ferrara, in order to find out more about a specific topic or even the general history of that place.

The question of the methods users employ to find this information is complicated by their adaptation to systems that exclude certain approaches, such as the possibility that a family itself might be an author. A collection of family photographs or the names and dates recorded in a family Bible are information documented by families as opposed to information about the families. The researcher in official records needs to worry about variant spellings because the indexes used do not distinguish between family as author or as subject. The searcher using an online catalog, however, does need to know that distinction. Because the distinction between the use of a family name as an author and as a subject is not intuitive, searchers in catalogs are likely to be frustrated until they interact with an information professional or an experienced researcher.

Research remains to be done about the information seeking needs and behavior of users studying family names. One constant is that those researchers find themselves examining variant spellings of family names and changes of family names. As they become more sophisticated and as archival materials appear more regularly in catalogs, researchers will need to be aware of families as authors.

\section{How Do Catalogers and Archivists Meet Those Needs?}

The third question is how family names have been regarded and established in the Anglo-American cataloging and 
archival traditions. Hitherto, descriptive catalogers seem to have considered families as entities incapable of authorship, or perhaps collections of persons who act independently of one another. The only way that AACR2 would consider families to be authors would be to regard them as multiple authors who may or may not share a name and may or may not work together. Any work or collection to which more than three members of a family have contributed would be entered under title (or given a work identifier as a title main entry), with at most one family member given an access point. ${ }^{21}$ Because descriptive catalogers have bowed out of the process of establishing family names, they have been established in library catalogs primarily as subject headings.

In the Library of Congress Subject Headings (LCSH), such names are established according to instructions in the Subject Cataloging Manual. ${ }^{22}$ The names of families are established as personal name headings from evidence of their usage and from reference sources, with particular emphasis given to telephone books. The Subject Cataloging Manual treats families and family names as rather fuzzy entities, and a family name may be established with a number of variants that become "see" references to the chosen heading, with no attention paid to the question of common descent (e.g., Lee family). ${ }^{23}$ The question of the relationship of the family to the family name also is not described in the instructions for LCSH. Why some names are established as separate headings and some become variant references to an established family name is unclear. Sometimes a family name that seems to be a variant of another is unrelated to it, and mistaken reference structures can be highly annoying to patrons. ${ }^{24}$

Why are some names that would appear to be related or variant orthographic forms not connected by references? For example, why is "Li family" established as a separate heading with no connection to "Lee family," when "Lie family" and "Yi family" are both connected to the "Lee family" by "see also" references? ?25 $^{25}$ Families whose surnames are translations of names in different languages (e.g., Smith and Schmidt, Faber and Favre) are connected by "see also" references, even if they share a common descent. When a family name has "changed substantially as a result of emigration," the names also are connected by "see also" references. The Subject Cataloging Manual also provides instructions for the formulation of the family names of ruling families, such as dynasties, noble or royal houses, or the possessors of a hereditary title, such as the Dukes of York. ${ }^{26}$ Apparently, no way exists to identify a non-ruling family in a society that has no surnames, a condition that was the case for many families of Asia and Africa until recently, and that is still true for some societies (e.g., Iceland and portions of Malaysia). ${ }^{27}$ Even in societies that have adopted surnames, people may not be identified by those surnames. In Turkey, telephone books listed individuals by given name long after surnames were adopted in the $1920 \mathrm{~s}^{28}$
In contrast to the descriptive cataloging tradition, the archival tradition in the United States has traditionally entered papers under the name of the family, as used by the family. ${ }^{29}$ Variant names become separate names, perhaps unconnected by references (e.g., Clark, Clarke, Clerk, LeClercq). The reasoning here is that people looking for their own family names are upset to find that the spelling they use is a "see" reference to what they consider a "wrong" spelling of their name. ${ }^{30}$ In the archival tradition, archivists choose the form of the name that is most commonly used in the collection, but recent archival rules are unclear about whether other forms are treated as variants with "see" references.

At this point, the most detailed rule in the United States context is in the Society of American Archivists' Describing Archives: A Content Standard (DACS). ${ }^{31}$ Rule 12.29 covers family names and states as a basic principle that "The heading for a family consists of the family surname followed by the term "family." The entry element should be the name by which the family is "commonly known" (12.29B); the sources for the name are based in descending order on the most frequent name in published works about the family, the name appearing most frequently in the archival materials being described, the latest name, and finally, the name appearing in references sources (12.29C). The British National Council on Archives gives more guidance, breaking family names down into "family name," epithet "family," title or occupation, and territorial designation allowing for qualification of families by those elements; e.g., Smith family of Lowestoft or Clerk family, chandlers ${ }^{32}$ Such a solution is impractical for the United States, where geographical and occupational mobility is so frequent.

The International Standard Archival Authority Record for Corporate Bodies, Persons, and Families, issued by the Ad Hoc Commission on Descriptive Standards of the International Council on Archives in 1996, prescribes what elements may be included in the name for an authority record but not how to decide how to construct a particular name. ${ }^{33}$ The second edition, published in 2004, provides examples of such records. ${ }^{34}$ Another international document, the Statement of International Cataloging Principles, does provide some guidelines on the formation of family names, but these are too brief to be of any help to the cataloger. ${ }^{35}$

\section{How Well Do Catalogers Help Users Find What They Need?}

The advantage of the LCSH method of using one heading for all families sharing a common surname (together with some variants of the surname) is that it provides collocation of different family groups. This advantage becomes a disadvantage to the researcher who is looking for one par- 
ticular family group of Smiths, Garcias, or Hashimotos. The archivists' solution suffers from the reverse problem. The researcher finds it easier to locate documents by and about a specific family grouping, but different families sharing the same name or variants of that name are not collocated ${ }^{36}$

Libraries and archives that have catalogs that integrate records for both published and archival materials are faced with a serious problem. If they use LCSH and the Library of Congress Name Authority File (NAF), librarians find that when they try to match headings in their archival descriptions, some names will be treated as variants to another form (and sometimes that variant form will be the most important in the context of the local community). Family name authority records will be coded to indicate that the names are not to be used as authors or added entries. If the online catalog requires separate searches for a term used as an author and as a subject, the user may be hindered in accessing materials. Libraries and archives have employed different solutions. Some libraries enter collections of family papers under title, include the name of the family in that title, and then use the LCSH form in the subject headings for the collection. Others use the particular form of the family name that appears in the record for both main and subject entries and either create local authority records or ignore the question of the LCSH headings and references. Some libraries use the name that is predominantly listed in the collection as the main entry and then use the LCSH form for subject access. All of these are half-measures to cope with an unsatisfactory situation. ${ }^{37}$

Other problems are posed by the existing rules for establishing family names. For example, the LCSH instructions for formulating family name subject headings provide no guidelines about what constitutes a family, or, more importantly, what distinguishes one family grouping from another. If subject catalogers were consistent in following the instructions contained in the Subject Cataloging Manual, things would be complicated enough. Unfortunately, as a few examples will show, catalogers face considerable difficulty in being consistent. How "see" references such as Botfield family, Bouteville family, and Botervile family can be considered variants of the Butterfield family or family name is unclear. ${ }^{38}$ Why was the Newcomb family changed to the Newcomer family with the Newcom, Newcome, and Newcombe references retained and considered to be the same family?

As mentioned previously, one of the weaknesses of the LCSH system is that it provides no way to distinguish specific family groups from larger family groups. How does one distinguish between the Creider family descended from Simeon Creider (who had eleven children) and the family composed of the descendants of one of those children? Could one treat the latter as a subheading of the main family? When do variant spellings become separate names? The fact that a given family name may or may not overlap with the family in question is also problematical. Does a "new" or different family come into existence when a member or several members of a family or families change their surname through emigration or through legal means? For example, a number of families in New York changed their surname from Hitler to other names during World War II. ${ }^{40}$ Did these become new families?

The literature on changing surnames is considerable. Although most of this literature is concerned with the reasons why people change names or legal niceties, perusal of the articles provides the cataloger (and family historian) with an idea of the immense problems these changes pose to those who wish to provide access to families and family names. ${ }^{41}$ Finally, LCSH and other current instructions for formulating family names are very Eurocentric, rooted in the modern state. ${ }^{42}$ None of the current instructions account for the fact that families are conceptualized very differently in different cultures and that this fact has an effect on what is signified by the name. For example, siblings in the Sudan could, and did, adopt different surnames. ${ }^{43}$ Scott, Tehranian, and Matthias describe the cultural presuppositions of officials who tried to assign family names to indigenous peoples in the United States and Canada, and the administrative chaos resulting from the clash of western family structures with the family naming pattern of those indigenous peoples. ${ }^{44}$

\section{Some Modest Proposals}

Family names are traditionally treated as a form of personal name. The MARC21 format codes them in the X00 fields, rather than in the 650 (topical subject heading) or the X10 fields used for corporate headings. ${ }^{45}$ Nonetheless, corporate bodies might well be considered a better analogy for families than personal names. This position was taken by the American, British, and Australian responses to the Library of Congress proposal for formulating family names. Only the Canadian response stated that personal names provide an adequate model for the formulation of family names. ${ }^{46}$

Strictly speaking, a family is a type of corporate body, in that it consists of a group of people and not one individual. More convincingly, families take actions as a group, even when one individual is primarily or legally responsible (moving, buying a house, entertaining). One such action is the creation of family records, which are quite analogous to category 1 in the current AACR2 (21.1B). Native American clans and similar groups of indigenous peoples in other continents own not only land, but also creative intellectual products, such as songs, dances, and stories. ${ }^{47}$ For example, native Alaskan artists working with the Sealaska Heritage Institute sign a statement saying, "I agree to comply with 
Southeast Alaska Native Traditional laws in respecting clan ownership of crests, names, songs, and other such cultural and intellectual property of clans." ${ }^{\text {"48 }}$ Even if an individual "authored" the song in such cases, the clan relationship is not simply that of subject.

As with other corporate bodies (e.g., college faculties, ecclesiastical chapters, and municipal governments), a family can take action over a long period of time. Different family members take actions (updating a family tree, selling property) on behalf of a family or affecting a family, just as the different members of a corporation may take individual actions (approving budgets, creating directives) on behalf of or affecting the corporation as a whole. A given individual may belong to and act as a member of different families simultaneously or sequentially, just as individuals may be members of different corporate bodies (companies, societies, religious groups, governments). Individuals may affiliate with a family in different ways (birth, adoption, marriage, free association), just as individuals may become a member of a corporate body in different ways (birth, adhesion through an oath or subscription, employment, fee, baptism, and so on). Families may or may not have a name designating them as a family, just as corporate bodies may or may not be named, although such groups would be generally designated somewhere in the material cataloged and then named by the cataloger.

The sources for the choice of a family name as given in DACS (12.29C) are analogous to those for a corporate body: "Determine the name by which a family is commonly known from the following sources and in the order of preference given: a) the name that appears most frequently in the published works about the family (if any); b) the name that appears most frequently in the archival materials being described; c) the latest name; d) the name that appears in reference sources." ${ }^{.49}$ That is, a cataloger rarely has access to works issued by a family, just as a cataloger frequently does not have access to a work emanating from a corporate body when cataloging an item about that body. Reference works assume a greater importance for establishing family and corporate names than for persons (other than individuals best known for activities other than created works). In contrast to the situation with personal names, a cataloger sometimes finds determining whether a particular name is a family name difficult, just as determining whether a specific group has a corporate name is not always possible. This problem grows even worse when dealing with different cultures and languages. 
Problems as well as advantages exist with the corporate body model for family names. Families change their names, often when crossing national borders. For example, when a German family settled in Baltimore in an Irish enclave, the family name of Bräutigam became Brantigan. ${ }^{50}$ Individuals were given new names at Ellis Island that they passed on to their descendants, although some accounts are probably apocryphal. ${ }^{51}$ Some families have changed names within a country. During World War I in this country, some GermanAmerican families anglicized their names. Are these different families? Are they earlier and later forms of the name? Or are they something else? When does a spelling variation become a new family name? For example, one of my ancestors, born in 1811, was listed as John Kreider in the 1830 and 1840 census records, and as John Greider in tax lists; that is clearly a variation. Somewhere in the 1850 s or 1860s, he settled on the spelling Creider. Since then, his descendants have, for the most part, used that form. Does that make these descendants a separate family from other Kreiders or Greiders?

The corporate name model breaks down in the form in which headings are established. Personal name headings are constructed with the surname first, when one is available. Corporate names are established in direct order, at least since the older pattern of Wilson, (H.W.) firm was abandoned by AACR in a change from earlier cataloging codes. ${ }^{52}$ Following the current pattern, one would have names such as Smith family, John W. Smith family, Paul Smith family, or Isabella Smith family. Without the support of an extensive reference apparatus, such patterns would be very hard on users who would have to guess how a particular name might be established, or researchers who wished to find works by or about different families sharing the same surname.

Corporate names are differentiated by the use of qualifiers of place or date. Application of this pattern to family names could result in headings such as John W. Smith Family (1753-1905), John H. Smith Family (1883-), Smith Family (Wooton Major, England), or Smith Family (John W., d. 1803). Inverting the names so that surname came first could result in forms such as Smith, John W., d. 1803 (Family); Smith, John W. (Family), d. 1803; Smith, John W., d. 1803, family; Smith Family (John W. Smith, d. 1803), or Smith Family (Wooton Major, England). None of these forms is particularly elegant.

Using the inverted form would preserve the analogy with personal names, but is hardly intuitive. The direct forms likely would involve less complicated encoding in MARC21 or similar standards, but would suffer from the problem of deciding which names need what qualifiers. Perhaps the last two examples, which use the surname plus the word "family" or a suitable equivalent and treat forenames as qualifiers along with place and date, might be the most useful for researchers. Whatever format is adopted will need extensive references from variant and related forms. However, the principle that the family name should be established on the basis of the work(s) referring to that family as author or subject will solve most of the problems, even if it also might result in a number of heading that would be connected by authority records.

The problem with adopting a rigid categorization for what constitutes a family name is that invariably alternatives are both conceivable and likely to occur to others. Social reality is infinitely more complex than any theories seem to be able to describe. The cataloger might be more effective describing families using their own terms instead of establishing firm conceptual boundaries that will be altered by historical developments or changes in social theory. This will involve abandoning LCSH's approach and adapting the pattern used by archivists. Basically, a family would be a group that called itself a family. Each specific family group would need to be differentiated from other groups with the same name, preferably one using that family's own terminology. This would allow the cataloger to identify families by using the terminology used by themselves or by others in writing about them without, for example, having to decide whether all Lee families include all Lea families. Differentiation between otherwise identical family names could be made by use of the qualifiers used by the source(s) of information for the heading.

Whatever approach the cataloging communities adopt to the formulation of family name headings, any solution will have to accommodate several needs. Family names will need to be used as named access points to materials described by catalogers. The same form of name for a specific family should be used in both name and subject headings. ${ }^{53}$ In order to meet international cataloging standards, the form of name will need to be specific to the family group involved and will need to be differentiable from other families with the same or similar surname. ${ }^{54}$ Family names may need to be connected to and distinguished from related groups by "see" and "see also" reference structures. In some cases, providing "see also" references between the names of individuals and the names of specific families analogously to performing groups may be useful. Headings will need to be constructed for unnamed family groups, if only for subject access. This last group will include family groups in cultures with no surnames. In such instances, catalogers will need to decide whether such unnamed groups can be authors.

The preceding paragraphs have suggested ways to meet these needs. Further study is necessary, particularly of cultural variations in the understanding of families and family names, the overlap and distinctiveness of families and family name both in general terms and in regards to specific families and family names (with its related question of change of name), and to family extent. The solutions to the formulations of family names as access points may become clearer 
after such study. The solutions catalogers adopt should be those that stem from cataloging principles applicable to other headings with the fewest special rules.

\section{References and Notes}

1. Julia Pettee, "Development of Authorship Entry and the Formulation of Authorship Rules As Found in the AngloAmerican Code," Library Quarterly 6 (July 1936): 270-90; J. C. M. Hanson, A Comparative Study of Cataloging Rules Based on the Anglo-American Code of 1908 (Chicago: Univ. of Chicago Pr., 1939); S. R. Ranganathan, Headings and Canons: Comparative Study of Five Catalogue Codes (Madras: S. Viswanathan, 1955).

2. International Federation of Library Associations, International Conference on Cataloguing Principles, Paris, 9th-18th October, 1961: Report (London: IFLA, 1963).

3. Charles A. Cutter, Rules for a Dictionary Catalog, 4th ed., rewritten (Washington: GPO, 1904); American Library Association and the (British) Library Association, Catalog Rules: Author and Title Entries, American ed. (Chicago: ALA, 1908); American Library Association, Division of Cataloging and Classification, Cataloging Rules for Author and Title Entries (Chicago: ALA, 1949); Anglo-American Cataloguing Rules, North American Text (Chicago: ALA, 1970).

4. Anglo-American Cataloguing Rules, 2nd ed., 1988 rev. (Ottawa: Canadian Library Assn.; London: Library Assn. Publishing; Chicago: ALA, 1988).

5. Cutter, Rules for a Dictionary Catalog, 46, rule 74; American Library Association and the (British) Library Association, Catalog Rules: Author and Title Entries, 32, rule 109; American Library Association, Division of Cataloging and Classification, Cataloging Rules for Author and Title Entries, 209-210, rule 114A.

6. Describing Archives: A Content Standard (Chicago: Society of American Archivists, 2004), 89, Chapter 9.

7. Deirdre Kiorgaard to Joint Steering Committee for Revision of AACR, "RDA Prospectus 19 June, 2006," www.collections canada.ca/jsc/docs/5rda-prospectusrev2.pdf (accessed July 26, 2006).

8. IFLA Meeting of Experts on an International Cataloguing Code, Statement of International Cataloguing Principles, (April 3, 2006 Draft), 5, principle 5.1.2.1, www.loc.gov/loc/ifla/ imeicc/source/Statement-draftsep05-clean.pdf (accessed July 27, 2006).

9. Memorandum from Barbara B. Tillett, LC representative, to Joint Steering Committee for Revision of AACR, Feb 28, 2006, rev. (5JSC/LC/6), www.collectionscanada.ca/jsc/docs/ 5lc6.pdf (accessed July 12, 2006).

10. Merriam-Webster Online Dictionary, www.m-w.com/diction ary/family (accessed July 13, 2006).

11. Joseph H. Lynch, Christianizing Kinship: Ritual Sponsorship in Anglo-Saxon England (Ithaca, N.Y.: Cornell Univ. Pr., 1998).

12. Christiane Klapisch-Zuber, "L’Aïeul des Généalogies Toscanes," Annales de Démographie Historique (1991): 103-12.
13. Oxford Latin Dictionary (Oxford, England: Clarendon Pr., 1968-1982); Charlton T. Lewis and Charles Short, A Latin Dictionary (Oxford, England: Clarendon Pr., 1879), http://perseus.uchicago.edu/hopper/search.jsp?doc=Perseus :text:1999.04.0059 (accessed August 2, 2006).

14. Patrick J. Geary, The Myth of Nations: The Medieval Origins of Europe (Princeton, N.J.: Princeton Univ. Pr., 2002); Giorgio Ausenda, ed., After Empire: Towards an Ethnology of Europe's Barbarians, Studies in Historical Archaeoethnology, vol. 1 (Woodbridge, England: Boydell Pr., 1995); Walter Pohl and Helmut Reinitz, eds., Strategies of Distinction: The Construction of Ethnic Communities, 300-800, The Transformation of the Roman World, vol. 2 (Leiden, Netherlands: Brill, 1998); Walter Goffart, Barbarian Tides: The Migration Age and the Later Roman Empire (Philadelphia: Univ. of Pennsylvania, 2006).

15. James C. Scott, John Tehranian, and Jeremy Mathias, "The Production of Legal Identities Proper to States: The Case of the Permanent Family Surname," Comparative Studies in Society and History 44, no. 1 (2002): 17-32.

16. Maura E. Hametz, “To Have What Was Mine’: Reclaiming Surnames in Trieste," Names 50, no. 1 (2000): 3-22.

17. Donald W. Larmouth, "Finnish Surname Change in Northern Minnesota," American Speech 62, no. 1 (1967): 31-37.

18. Richard D. Alford, Naming and Identity: A Cross-cultural Study of Personal Naming Practices (New Haven, Conn.: HRAF Pr., 1988); International Federation of Library Associations and Institutions, IFLA Universal Bibliographic Control and International MARC Programme, Deutsche Bibliothek, Frankfurt am Main, Names of Persons: National Usages for Entry in Catalogues, UBCIM publications, new series, vol. 16 (Munich: K. G. Saur, 1996).

19. Mavis Bertha Molto, "Textual Regularities Applicable to FullText Searching: The Case of Family History Literature" (Ph. D. diss. University of California, Los Angeles, 1989); David Hey, "Family Names and Family History," History Today 51, no. 7 (2001): 38-40; David Hey, "Recent Advances in the Study of Surnames," Historian 80 (2003): 13-17.

20. FamilyTreeMaker.com, User Home Pages for the Hostetters, http://familytreemaker.genealogy.com/users/h/o/s/Rick-L -Hostetter/GENE0001-0005.html (accessed Aug. 2, 2006); Richard L. Hostetter, The Hostetter Family (Baltimore: Gateway Pr., 1984).

21. Anglo-American Cataloguing Rules, 2nd ed., 1998 rev., rules 21.6-7.

22. Library of Congress, Office for Subject Cataloging Policy, Subject Cataloging Manual: Subject Headings (Washington, D.C.: Cataloging Distribution Service, Library of Congress, 1990-) H1631, 3, "Names of Individual Families."

23. Library of Congress Subject Authority Record sh 85075685. OCLC WorldCat (proprietary database, accessed July 27, 2006).

24. Donald E. Lenfest, "Lenfestey-Lenveiset: A Case of Mistaken Identity," Names 28, no. 1 (1980): 32-42.

25. Library of Congress Subject Authority Records sh 8800166 (Li family), sh 85076785 (Lie family), sh 87001336 (Yi family) and sh 85075685 (Lee family), OCLC WorldCat (proprietary database, accessed July 27, 2006). 
26. Library of Congress, Subject Cataloging Manual, H 1574 "Dynasties, Royal Houses, Etc."

27. IFLA, Names of Persons, 45-46 (Cameroon), 71-72 (Gambia), 91 (Iceland), 145-49 (Malaysia), 155-58 (Myanmar); Sushma Gupta, "Cataloging Ethiopian Personal Names," Cataloging \& Classification Quarterly 14, no. 2 (1991): 81-92.

28. Scott, Tehranian, and Mathias, "Production of Legal Identities."

29. Library of Congress, "Manuscripts File Becomes Mixed Materials File,” LC Cataloging Newsline 5, no. 6 (May 1997), www.loc.gov/catdir/lccn/lccn0506.html (accessed Nov. 20, 2006).

30. Charles Clement, Ottilia Koel, and Mary Lou Miller, "Where Is the Solution: What Is the Problem?” RQ 24 (Spring 1985): 282-84.

31. Describing Archives, 152, Rule 12.29.

32. National Council on Archives, "Rules for the Construction of Personal, Place, and Corporate Names: 2.6 Family Names," www.archivesnetworkwales.info/ncarules/rules2.htm\#Family (accessed July 27, 2006).

33. Ad Hoc Commission on Descriptive Standards of the International Council on Archives, International Standard Archival Authority Record for Corporate Bodies, Persons, and Families, 2nd ed. (Ottawa: Secretariat of the ICA Ad Hoc Commission on Descriptive Standards, 2004), www.ica .org/biblio/isaar_eng.html (accessed July 24, 2006)

34. International Council on Archives, ISAAR (CPF) International Standard Archival Authority Record for Corporate Bodies, Persons and Families (Paris: International Council on Archives, 2004), www.ica.org/biblio/ISAAR2EN.pdf (accessed July 24, 2006).

35. IFLA Meeting of Experts on an International Cataloguing Code, Statement of International Cataloguing Principles.

36. Clement, Koel, and Miller, "Where Is the Solution?"

37. Ibid; Beinecke Rare Book and Manuscript Library, Beinecke Manuscript Unit, Orbis Cataloging Manual, Mixed Materials Format, Appendix Q, Family Names (New Haven, Conn.: Beinecke Rare Book and Manuscript Library, 1997), www .library.yale.edu/beinecke/manuscript/mscat/aapQ/htm (accessed July 27, 2006).

38. Library of Congress Subject Authority Record sh 85018379. OCLC WorldCat (proprietary database, accessed May 16, 2006).

39. Library of Congress Subject Authority Record sh 85091549. OCLC WorldCat (proprietary database, accessed May 23, 2006).

40. Robert M. Rennick, "Hitlers and Others Who Changed Their Names and a Few Who Did Not," Names 17, no. 3 (1969): 199-207.

41. James E. Jacob and Pierre L. Horn, "Comment vous appelezvous?: Why the French Change Their Names," Names 46, no. 1 (1998): 3-28; Hametz, "To Have What Was Mine"; Scott, Tehranian, and Mathias, "Production of Legal Identities"; Judith M. Law, "Name Change and Identity Redefinition: A Symbolic Interactionist Perspective" (Ed. D. diss., Alliant International Univ., 2003).

42. Scott, Tehranian, and Mathias, "Production of Legal Identities," 29-35.
43. Gregory Mann, "What's in an Alias? Family Names, Individual Histories, and Historical Method in the Western Sudan," History in Africa 29 (2002): 309-22.

44. Scott, Tehranian, and Mathias, "Production of Legal Identities."

45. Library of Congress, Network Development and MARC Standards Office, MARC21 Concise Format for Bibliographic Data, 2005 Concise ed., www.loc.gov/marc/bibliographic/ ecbdhome.html (accessed July 24,2006).

46. Memorandum from Hugh Taylor, CILIP [Chartered Institute of Library and Information Professionals] representative, to Joint Steering Committee for Revision of AACR2, 25 March 2006 (5JSC/LC6/CILIP response), www.collections canada.ca/jsc/docs/5lc6-cilipresp.pdf (accessed July 24, 2006); Memorandum from Diedre Kiogaard, ACOC [Australian Committee on Cataloging] representative to JSC [Joint Steering Committee for the Revision of AACR2], to Joint Steering Committee for Revision of AACR2, 27 March, 2006 (5JSC/LC/6/ACOC response), www.collectionscanada.ca/jsc/docs/5lc6-acocresp.pdf (accessed June 12, 2006); Memorandum form Jennifer Bowen, ALA representative, to Joint Steering Committee for Revision of AACR2, 27 March 2006 (5JSC/LC/6/ALA response), www.collections canada.ca/jsc/docs/5lc6-alaresp.pdf (accessed July 12, 2006); Memorandum from Canadian Committee on Cataloging to Joint Steering Committee for Revision of AACR2, 24 March, 2006 (5JSC/LC/6/CCC response), www.collectionscanada .ca/jsc/docs/5lc6-cccresp.pdf (accessed July 12, 2006).

47. Nancy J. Turner and James T. Jones, "Occupying the Land: Traditional Patterns of Land and Resource Ownership among First Peoples of British Columbia” (paper presented at Constituting the Commons: Crafting Sustainable Commons in the New Millennium, the Eighth Conference of the International Association for the Study of Common Property, Bloomington, Indiana, USA, May 31-June 4, 2000), http:// dlc.dlib.indiana.edu/archive/00000371 (accessed August 1, 2006); Jill Bevan-Brown, "Providing a Culturally Responsive Environment for Gifted Maori Learners," International Education Journal 6, no. 2 (2005): 150-55, http://ehlt.flinders .edu.au/education/iej/articles/v6n2/Bevan/paper.pdf (accessed July 31, 2006);

48. Sealaska Heritage Institute, "Native Artist Waiver, Release and Certification: Enhancing Tlingit, Haida, and Tsimshian Art" (Juneau: Sealaska Heritage Institute, 2006), www.alaska nativeartists.com/application_native_artists_market_2006.pdf (accessed Aug. 1, 2006).

49. Describing Archives, 152

50. Conversation with Martha Brantigan-Stowell, ALA Midwinter Meeting, San Antonio, Texas, Jan. 2006.

51. Robert M. Rennick, "The Inadvertent Changing of NonEnglish Names by Newcomers to America: A Brief Historical Survey and Popular Presentation of Cases," New York Folklore Quarterly 26, no. 4 (1970): 263-82.

52. Anglo-American Cataloguing Rules, 111, rule 65D2. This is a change from the other codes cited in endnote 3 above.

53. Robert Maxwell, e-mail message to author, May 31, 2006.

54. IFLA Meeting of Experts on an International Cataloguing Code, Statement of International Cataloguing Principles, principles 5.1.2.1.1-2 and 5.3. 